\title{
Effect Of The Use Of Tutorial Methods On Liveliness Of Students In Midwifery On Askeb I In Akbid Nyai Ahmad Dahlan Yogyakarta
}

\author{
Stefi Fivtri Lestari De Flores \\ Midwife Educator Study Program at DIV Aisyiyah College of Health Sciences Yogyakarta
}

ARTICL EINFO

Keywords:

tutorial method (seven jump), liveliness of learning, students
E-mail:

stefifivtrilestarideflores123@gmail.com
ABSTRACT
One form of the learning process with the Competency-Based Curriculum (KBK) system is to use the tutorial method. The role of student learning in tutorials is essentially a group discussion process that requires management skills. The success of the tutorial discussion will be greatly influenced by the stages of the structure that must be followed by students which is called the Seven Jump method. This study aims to determine the effect of using the tutorial method (seven jumps) on the learning activities of midwifery second semester DIII students in the Midwifery Care course I at the Nyai Ahmad Dahlan Midwifery Academy, Yogyakarta in 2013. This study used a quasi-experimental design. Using a non-equivalent control group design. The sample in this study amounted to 37 people with the distribution of 15 samples as the experimental group and 22 samples as the control group. Data analysis using frequency distribution and bivariate analysis using Wilcoxon match paired test statistic. Based on the research conducted, the results showed that there was a significant increase in student activity in the second semester of Midwifery DIII in Midwifery Care Courses I Pre and Post Test in the Experimental Group $\mathrm{p}=0.001<0.05$. The increase before and after the intervention was 18.73. There was no significant increase in student activity in the second semester of DIII Midwifery in Midwifery Care Courses I Pre and Post Test in the Control Group $\mathrm{p}=$ $0.928>0.05$. The difference before and after the intervention was 0.04 .

Copyright (C) 2020 Eduhot Journal.All rights reserved.

is Licensed under a Creative Commons AttributionNonCommercial 4.0 International License (CC BY$\mathrm{NC} 4.0)$

\section{INTRODUCTION}

The development of midwifery services and education is constantly evolving. The development of midwifery education goes hand in hand with the development of midwifery services to answer the demands and needs of the community for quality midwifery services[1]. The quality of education in Indonesia is currently very concerning. This is evidenced, among others, by UNESCO data (2008) on the ranking of the Human Development Index. According to the Political and Economic Risk Consultant (PERC) survey, the quality of education in Indonesia is ranked 69th out of 127 countries in 
the world and 34th in Asia. Law No. 20 of 2003 concerning the national education system states that education is a conscious and planned effort to create a learning atmosphere and learning process so that students actively develop their potential to have religious spiritual strength, self-control, personality, intelligence, noble character and the necessary skills. himself, society, nation and state[2]. The view of the long-standing learning process that places learning as a process of transferring information or transfer of knowledge from teachers to students is getting more and more criticism. The placement of teachers as the only source of information places students or students not as dynamic individuals, but rather as passive objects so that their individual potentials do not develop optimally.[3]. Broadly speaking, Ki Hadjar Dewantara also stated that education is an effort to advance one's character, mind, and body. According to him, these three elements cannot be separated in order to achieve the perfection of life. Based on his ideas, when compared with current education and teaching, it is even less independent. One of them can be seen from teaching that still applies conventional subject-object methods and humanizes students.

Less effective learning process affects learning activity so that it affects learning outcomes, namely student learning achievement and competence in the world of work after education. Many studies have shown that the current graduates of midwives are still not able to answer the challenges of the need for midwifery services or it can be said that the graduates produced today are still not qualified. The above statement is further reaffirmed by data which states that in Indonesia, midwifery institutions are growing rapidly, it is proven that currently there are more than 729 midwifery DIII educational institutions, both public and private, all of which are involved in maternal and child health services. Especially in Yogyakarta, there are approximately 17 public and private DIII midwifery institutions.[4]. However, the performance of reducing the Maternal Mortality Rate (MMR) is still low, in 1990 the maternal mortality rate was $390 / 1000 \mathrm{Kh}$ and in 2007 it was only achieved $228 / 1000 \mathrm{KH}$, while the target of $102 / 100,000 \mathrm{KH}$ in 2015 . Government policy in implementing the MDG's program is the expansion of health services that quality, comprehensive obstetric services, improvement of family planning services, dissemination of communication, information and education to the community. However, efforts to reduce maternal mortality are not without problems[5]. In this case the midwife is one of the health workers who have a role in midwifery services, management of midwifery services, educators and researchers.[6]. The community as our stakeholder does not only need large quantities, but also maximum quality. So that the image of midwives among other professions is not only as a collector of rupiah coffers, but as a builder of women in cyberspace[7]. Midwives who are the spearhead of improving maternal and child health, in optimizing their role, the need is increasingly important to provide systematic and directives towards quality teaching to midwife students.[8]. Especially in quality midwifery care for pregnant women, one of the important subjects that must be mastered by prospective midwives[9] [10].

At the university level, the Minister of National Education regulates the curriculum through Decree No. 045/U/2002 which states that the higher education curriculum is competency-based. These regulations affect the paradigm of the higher education system in Indonesia. Some of the factors that influence the change in education in Indonesia, from teacher centered learning to student centered learning, among others, changes globally include increasingly fierce competition followed by changes in the orientation of educational institutions, namely changes in work requirements described in the core and institutional curriculum no 232/U/2000[11]. One form of the learning process with the Competency-Based Curriculum (KBK) system is to use the tutorial method[12]. This learning method is expected to lead to active learning so that students learn more actively which is a force that can be a driving force for students to utilize the potential that exists in students and potential outside themselves to realize learning goals.[13].

The results of a preliminary study conducted by researchers at the Nyai Ahmad Dahlan midwifery academy, which still uses the old curriculum, are in line with the mission of the Nyai Ahmad Dahlan midwifery academy in an effort to improve the quality of learning and produce quality midwives to make the MDG's program a success. One of the strategies is to actively prepare oneself to change the educational paradigm by switching to competency-based education and collaborating with the Papua Foundation which was founded by dr. Felix Duit in producing quality midwives in Eastern Indonesia. The researcher received information from the director of the Midwifery Academy 
Nyai Ahmad Dahlan and was strengthened by one of the student affairs staff who also said that the second semester students of 37 students, 36 people came from the Papua area. Based on this cultural background, students tend to be inactive. Various ways have been carried out by the institution in increasing the activity and activity of students. This is one of the institutional challenges. The results of preliminary studies that have been carried out at Akbid Nyai Ahmad Dahlan, especially for level I students in the second semester and from interviews with lecturers, it is found that there are problems in the learning process which include: Students are less active in the teaching and learning process, where only a small number of students want to ask questions. ; 2) less active learning so that the understanding of the material is not deep; the complete program set by the institution has not been achieved, marked by the presence of students who get an achievement index score of less than 3,0 (B) of 27 students out of 37 students so it is necessary to follow the process of improving grades. The learning method still uses the lecture method, so that the lecturer becomes a more active party to achieve the material and students listen to the lecturer's explanation. Efforts to overcome the problems that occur, including the need for the use of learning methods and media that can foster learning activity so that students are more active in interacting during the learning process. The activeness of these students will create an effective learning process and optimal learning outcomes (Suprijono, 2012). Based on the problems above,

\section{METHOD}

This study uses an analytical survey method, which is a research method carried out with the aim of finding out whether there is a relationship without treatment. In this case, the researcher is looking for a relationship between students' perceptions of the performance of lecturers and the learning outcomes of the fourth semester DIII Midwifery students in the ... at STIKES 'Aisyiyah' Yogyakarta. The time approach used is retrospective, namely research that seeks to look back, meaning that data collection starts from the effects or consequences that have occurred, then from these effects the settlement or variables that influence the consequences are traced.

The variables disclosed in this study are:

a. The independent variable in this study is the student's perception of the lecturer's performance.

b. The dependent variable in this study is the learning outcomes of the fourth semester DIII Midwifery students in the ... at STIKES 'Aisyiyah' Yogyakarta.

c. Confounding variables in this study are environmental factors, instrumental factors, physiological factors, psychological factors, cognitive abilities.

Students' perceptions of lecturer performance are students' perspectives on work abilities or achievements shown by lecturers regarding services to DIII Midwifery students as a policy to achieve goals, especially in achieving learning outcomes. In this case, the value of students' perceptions of lecturer performance is seen from the number of scores, namely:

\begin{tabular}{ll}
\multicolumn{1}{c}{ Criteria } & \multicolumn{1}{c}{ Scale } \\
\hline Very good & $76 \%-100 \%$ \\
Well & $51 \%-75 \%$ \\
Not good & $26 \%-50 \%$ \\
Very Not Good & $0 \%-25 \%$
\end{tabular}

Student learning outcomes for midwifery care courses for family planning services ais the result achieved by each student after getting his learning experience. This value is expressed by an interval scale and the criteria used are:

\begin{tabular}{lll}
\multicolumn{1}{c}{ Score } & \multicolumn{1}{c}{ Information } & \multicolumn{1}{c}{ Scale } \\
\hline Point a & Very well & 4 \\
B value & Well & 3 \\
C Nilai & Enough & 2 \\
Value & & \\
D value & Not enough & 1 \\
E Nilai & Fail & 0
\end{tabular}

Effect Of The Use Of Tutorial Methods On Liveliness Of Students In Midwifery On Askeb I In AKBID Nyai Ahmad Dahlan Yogyakarta, Stefi Fivtri Lestari De Flores 
value

The population that will be taken in this study are all fourth semester DIII Midwifery students at Stikes 'Aisyiyah Yogyakarta 2013 totaling 225 students.

\section{RESULTS AND DISCUSSION}

Respondents in this study were D III Midwifery students in the second semester of Midwifery Academy Nyai Ahmad Dahlan Yogyakarta.

Table. 1 Characteristics of second semester students of DIII Midwifery Study Program Nyai

Ahmad Dahlan Yogyakarta.

\begin{tabular}{lcc} 
Characteristics & Frequency & Percentage \\
\hline Age & & \\
$<20$ & 28 & 75.6 \\
$>20$ & 9 & 24.4 \\
GPA & & \\
Well & 3 & 8.1 \\
Enough & 15 & 40.5 \\
Low & 19 & 51.4 \\
Original & & \\
Address & & \\
Java & 1 & 2.7 \\
Outside Java & 36 & 97.3 \\
\hline Total & $\mathbf{3 7}$ & $\mathbf{1 0 0}$
\end{tabular}

Based on Table. It can be seen that respondents aged $<20$ years are 28 respondents $(75.6 \%)$ and respondents aged $>20$ years are 9 respondents $(24.4 \%)$. The GPA of respondents who fall into the low category (GPA $<2.5)$ is 19 respondents $(51.4 \%)$, and the GPA of respondents who fall into the Good category is 7 respondents $(18.9 \%)$, respondents from Java are a number of 1 respondent $(2.7 \%)$, and respondents from outside Java are 36 respondents (97.3\%).

The results of the normality test showed that the significance value of the pre-test of midwifery students in the second semester of DIII midwifery in the Midwifery Care course I was 0.000; for the post-test of student activeness in the second semester of midwifery DIII in the Midwifery Care course $\mathrm{I}$, it is 0.001 . Because the significance for all variables is less than 0.05 , it can be concluded that the data are not normally distributed.

Table.2 Classification of activity in the experimental group

\begin{tabular}{|c|c|c|c|c|}
\hline No & Activity & $\begin{array}{l}\text { Pre-test } \\
\text { score } \\
\text { mean }\end{array}$ & $\begin{array}{l}\text { Post test } \\
\text { score Mean }\end{array}$ & Difference \\
\hline \multirow[t]{3}{*}{ A } & Visual activities & & & \\
\hline & 1. Search and read literature & 2.40 & 3.26 & 0.86 \\
\hline & 2. Observing how friends learn & 2.26 & 3.53 & 1.27 \\
\hline \multirow[t]{5}{*}{ B } & Oral activities & & & \\
\hline & Opinions in lectures or discussions & 2.66 & 3.06 & 0.44 \\
\hline & $\begin{array}{l}\text { Answering questions from the results of the } \\
\text { analysis }\end{array}$ & 2.26 & 3.00 & 0.74 \\
\hline & $\begin{array}{l}\text { Participate in active discussions based on the } \\
\text { literature that has been obtained }\end{array}$ & 2.66 & 3.2 & 0.54 \\
\hline & Active in brainstorming & 2.4 & 2.9 & 0.50 \\
\hline \multirow[t]{4}{*}{$\mathbf{C}$} & Listening activities & & & \\
\hline & $\begin{array}{l}\text { Can express ideas or ideas when listening to } \\
\text { friends in opinion discussions }\end{array}$ & 2.26 & 3.4 & 1.14 \\
\hline & $\begin{array}{l}\text { Listen to your friend's opinion carefully } \\
\text { before responding. }\end{array}$ & 2.86 & 3.46 & 0.60 \\
\hline & Keep up with ongoing discussions & 2.13 & 3.66 & 1.53 \\
\hline D & Writing activities & & & \\
\hline
\end{tabular}


Doing assignments and looking for literature seriously

Note down important things and things I don't understand

E Drawing activities

Can formulate learning objectives by making concept maps

Can draw a concept map of a given case

F Motorcycle activities

trying to formulate learning goals after lectures

learn by making a concept map or summary after the lecture is over

G Mental activities

Think critically when receiving information

The learning resources that I use vary

Think deeply to find solutions and solve problems

H Emotional activities

When there is a rowdy in the discussion, reminding the discussion members to be serious

Trying to do the work on your own without the help of others

Excited if the discussion is active
2.53

2.33

2.33

2.4

2.06

2.06

2.93

0.40

3.06

0.73

3

3.33

0.93

3.53

1.47

3.53

1.53

\section{2 \\ 2.46}

3.3

2.9

1.1

2.26

3.66

0.5

1.40

2.26

3.2

0.94

2.53

3.2

0.67

2.26

3.26

1.00

Table 3. Frequency Distribution of Respondents Based on Student Learning Activities in the Experimental Group $(\mathrm{N}=15)$

\begin{tabular}{ccccc} 
Learning Activity & \multicolumn{2}{c}{ Pre-Test } & \multicolumn{2}{c}{ Post Test } \\
& N & \% & N & \% \\
\hline Low & 8 & 53.3 & 1 & 6.7 \\
Currently & 4 & 26.7 & 4 & 26.7 \\
Tall & 3 & 20.0 & 10 & 66.7 \\
\hline Total & 15 & 100 & 15 & 100
\end{tabular}

Table 3 shows the learning activity of second semester DIII Midwifery students in Midwifery Care Course I in the experimental group in the pre test with the highest percentage in the low learning activity category as many as 8 respondents $(53.3 \%)$, while the lowest percentage in the high learning activity category as many as 3 respondents $(20.0 \%)$. Table 4 shows the learning activity of the second semester DIII Midwifery students in the Midwifery Care Course I in the experimental group in the post test with the highest percentage in the high learning activity category as many as 10 respondents $(66.7 \%)$, while the lowest percentage with the low learning activity category as many as 1 respondent $(6.7 \%)$.

\begin{tabular}{|c|c|c|c|c|}
\hline No & Activity & $\begin{array}{l}\text { Pre-test } \\
\text { score } \\
\text { mean }\end{array}$ & $\begin{array}{l}\text { Post test } \\
\text { score Mean }\end{array}$ & Difference \\
\hline \multirow[t]{3}{*}{$\mathbf{A}$} & Visual activities & & & \\
\hline & 1. Search and read literature & 2.45 & 2.45 & - \\
\hline & 2. Observing how friends learn & 2.27 & 2.4 & 0.27 \\
\hline \multirow[t]{3}{*}{ B } & Oral activities & & & \\
\hline & Opinions in lectures or discussions & 2.72 & 3.2 & 0.5 \\
\hline & Answering questions from the results of the & 2.3 & 2.7 & 0.4 \\
\hline
\end{tabular}


analysis

Participate in active discussions based on

$\begin{array}{lll}2.9 & 3.2 & 0.3 \\ 2.4 & 2.9 & 0.4 \\ 2.54 & 2.3 & -0.2 \\ 2.9 & 2.5 & -0.4 \\ 2.27 & 2.5 & 0.37 \\ 2.59 & 2.85 & 0.26 \\ 2.4 & 2.2 & -0.2\end{array}$

the literature that has been obtained

Active in brainstorming

C Listening activities

Can express ideas or ideas when listening to

friends in opinion discussions

Listen to your friend's opinion carefully before responding.

Keep up with ongoing discussions

D Writing activities

Doing assignments and looking for literature seriously

Note down important things and things I

2.4

2.2

$-0.2$

don't understand

E Drawing activities

Can formulate learning objectives by making concept maps

Can draw a concept map of a given case

2.45

2.3

$-0.1$

$2.5 \quad-3.2$

F Motorcycle activities

trying to formulate learning goals after lectures

learn by making a concept map or summary

2.3

2.5

0.2

after the lecture is over

2.3

2.5

0.2

G Mental activities

Think critically when receiving information

2.63

2.1

$-0.5$

The learning resources that I use vary

2.68

Think deeply to find solutions and solve

2.27

2.4

0.2

problems

H Emotional activities

When there is a rowdy in the discussion,

serious

Trying to do the work on your own without the help of others

Excited if the discussion is active

Table 5. Frequency Distribution of Respondents Based on Student Learning Activities in the Control Group $(\mathrm{N}=22)$

\begin{tabular}{lllll} 
Learning Activity & Pre-Test & \multicolumn{2}{c}{ Post Test } \\
& N & \% & N & \% \\
\hline Low & 9 & 40.9 & 10 & 45.5 \\
Currently & 8 & 36.4 & 7 & 31.8 \\
Tall & 5 & 22.7 & 5 & 22.7 \\
\hline Total & 22 & 100 & 15 & 100
\end{tabular}

Table 5 shows the learning activity of the second semester DIII Midwifery students in the Midwifery Care Course I in the control group in the pre-test with the highest percentage in the low 
learning activity category as many as 9 respondents (40.9\%), while the lowest percentage in the high learning activity category as many as 5 respondents $(22.7 \%)$.

Table . 6 Differences in Pre and Post Test Learning Activities in the Experimental Group $(\mathrm{N}=15)$

\begin{tabular}{|c|c|c|c|c|}
\hline Variable & mean & SD & $\begin{array}{l}\text { Different } \\
\text { Mean }\end{array}$ & $\mathbf{P}$ \\
\hline Pre test & 49.80 & 10,241 & & \multirow[b]{2}{*}{0.001} \\
\hline Post test & $\begin{array}{l}18.73 \\
68.53\end{array}$ & 9280 & & \\
\hline
\end{tabular}

From the table. 6 shows the results of the Wilcoxon statistical test of student activity in the second semester of Midwifery DIII in Midwifery Care Course I pre-test and post-test of the experimental group. In the analysis of student activity in the second semester of DIII Midwifery in Midwifery Care Course I pre shows mean $=49.80$ with a standard deviation of 10.241. Analysis of student activity in the second semester of DIII Midwifery in Midwifery Care Course I in the post test showed mean $=68.53$ with a standard deviation of 9.280. The increase before and after the intervention was 18.73 with $p=0.001$. Therefore, $p(0.001<0.05)$ means that there is a significant increase in the learning activity of the second semester DIII Midwifery students in the Midwifery Care Course I Pre and Post Test in the Experimental Group.

Table. 7 Differences in Active I Pre and Post Test in the Control Group $(\mathrm{N}=15)$

\begin{tabular}{clccc} 
Variable & \multicolumn{1}{c}{ mean } & \multicolumn{1}{c}{ SD } & $\begin{array}{c}\text { Different } \\
\text { Mean }\end{array}$ & P \\
\hline Pre test & 52.18 & 11,194 & & 0.928 \\
& 0.04 & & &
\end{tabular}

Table 7 shows the results of the Wilcoxon statistical test on student activity in the second semester of DIII Midwifery in the Midwifery Care Course I pre-test and post-test of the control group. In the analysis of student activity in the second semester of DIII Midwifery in Midwifery Care Course I pre shows mean $=52.18$ with a standard deviation of 11,194 . Analysis of the learning activity of the second semester DIII Midwifery students in the Midwifery Care Course I in the post test showed mean $=52.14$ with a standard deviation of 11.281. The decrease before and after the intervention was 0.04 with $\mathrm{p}=0.928$. Therefore, $\mathrm{p}(0.928>0.05)$ means that there is no significant increase in student activity in the second semester of DIII Midwifery in the Midwifery Care Course I Pre and Post Test in the Control Group.

\subsection{DISCUSSION}

Based on table 1, the activities of second semester students to participate in learning consist of visual activities, oral activities, listening activities, writing activities, drawing activities, motor activities, mental activities, emotional activities, which are known to answer the questionnaire. From table 1 Visual activities such as paying attention, reading and paying attention to the work of others. Student active activities seen from Visual activities there are two statements. The statement with the lowest increase was in the statement of actively seeking and reading literature, the mean pre-test value was 2.40 and the post-test mean value was 3.26 , an increase of 0.86 . With tutorials or small group learning, participants are given the opportunity to learn from other participants in accepting responsibility for completing the assigned tasks. In this study the increase was only 0.86 . This could be due to several factors in the field such as the lack of complete books in the library, the lack of electronic means to support the use of the internet. Expressing opinions, discussing, asking, stating, these are referred to as types of learning activities Oral Activities. Judging from the statement table for the increase in the result of the difference between the mean pre-test and the lowest post-test, namely the opinion in lectures or discussions, the pre-test score obtained the mean value of 2.66 and the post-test mean value of 3.06 with a difference of both 0.44 . The tutorial method is able to foster discussion, comments, interaction critique in providing brainstorming. Listening activities, are active activities for example listening: conversational discussions, music, speeches. In this activity, there is 
an increase in activity as seen from the mean pre-test and post-test values for each statement. The statement with the lowest improvement value is listening to the opinion of friends carefully before responding by 0.60 . In the tutorial process in the research, the respondents did not understand how to behave when they were about to express an opinion, for example cutting off a friend who was having an opinion, connecting other participants' words, not asking permission when they wanted to have an opinion. Writing activities are writing activities. Write stories, conversation results, conclusions, reports, questionnaires or copy (Sardiman, 2011). Of the two questions, The statement of the lowest increase in activity is doing assignments and searching for literature, the increase in activeness is seen from the results of the mean pre-test value is 2.53 and the mean post-test is 2.93 . The result of the difference between the mean post-test and the mean pre-test is 0.40 .

In research conducted by researchers, before entering the 6th step in seven jumps, respondents were given the task of finding and summarizing the material based on the agreed Learning Objectives, only 8 participants collected assignments, 5 participants collected during the tutorial step 6 entry and 3 others during the research. have been completed. The other seven participants still promised to collect them. Activity is also characterized by drawing activities, activities marked by, for example, drawing, making graphs, maps and diagrams (Sardiman, 2011). Of the two statements in the questionnaire, the lowest increase in the statement of making concept maps, there was an increase in activeness seen from the results of the mean value of pre-test was 2.4 and mean value of post-test was 3.33. The result of the difference between the mean post-test and the mean pre-test is 0.93 . According to the researcher, because tutor participants are not used to using concept maps so they must be assisted, the researcher suggests to students to practice often so that they know the learning objectives. So that it is easier to understand the material, both midwifery care materials and other materials. According to Gagne, one of the learning events is to increase retention (Enhance retention and recall) or the retention of the material being studied so that it is not forgotten that the teacher and students themselves can try to repeat the lesson frequently. Another way is to give lots of examples, using tables, concept maps and pictures. The activity is marked by motor activities. From the two statements above, there is an increase in activity as seen from the results of the mean value of the pre-test is 2.3 and the mean value of the post-test is 2.5. The result of the difference between the mean post-test and the mean pre-test is 0.2 with the statement trying to formulate learning objectives after completing recovery. And the second statement, namely learning to make concept maps or a summary of the material that has been studied, the increase in activity can be seen from the results of the mean value of the pre-test is 2.06 and the mean value of the post-test is 3.53. The result of the difference between the mean post-test and the mean pre-test is 0.40 . Student activity can be seen training themselves in solving problems or similar problems so that they can find out the learning objectives. In Gagne's theory also suggests the existence of an informed learner of objectivities or telling learning objectives, telling learning objectives also helps focus students' minds on relevant aspects. Mental activities, such as: taking interest, bored, excited, excited, excited, calm. In the statement of learning resources that are used vary, the increase in activity can be seen from the results of the mean value of the pre-test is 2.46 and the mean value of the post-test is 2.9. The result of the difference between the mean post-test and the mean pre-test is 0.5 . Respondents only look for reference sources in the campus library. The campus library does not have many book references so that every student uses the same reference. Emotional activities, such as being interested, feeling bored, happy, excited, excited and calm. In the excited statement if the discussion is active, the increase in activeness can be seen from the results of the mean value of the pre-test is 2.26 and the mean value of the post-test is 3.26 . The result of the difference between the mean post-test and the mean pre-test is 1.00. passionate, calm. In the statement of learning resources that are used vary, the increase in activity can be seen from the results of the mean value of the pre-test is 2.46 and the mean value of the post-test is 2.9 . The result of the difference between the mean post-test and the mean pre-test is 0.5 . Respondents only look for reference sources in the campus library. The campus library does not have many book references so that every student uses the same reference. Emotional activities, such as being interested, feeling bored, happy, excited, excited and calm. In the excited statement if the discussion is active, the increase in activeness can be seen from the results of the mean value of the pre-test is 2.26 and the mean value of the post-test is 3.26. The result of the difference between the mean post-test and the 
mean pre-test is 1.00. passionate, calm. In the statement of learning resources that are used vary, the increase in activeness is seen from the results of the mean value of the pre-test is 2.46 and the mean value of the post-test is 2.9. The result of the difference between the mean post-test and the mean pretest is 0.5 . Respondents only look for reference sources in the campus library. The campus library does not have many book references so that every student uses the same reference. Emotional activities, such as being interested, feeling bored, happy, excited, excited and calm. In the excited statement if the discussion is active, the increase in activeness can be seen from the results of the mean value of the pre-test is 2.26 and the mean value of the post-test is 3.26 . The result of the difference between the mean post-test and the mean pre-test is 1.00 . In the statement of learning resources that are used vary, the increase in activeness is seen from the results of the mean value of the pre-test is 2.46 and the mean value of the post-test is 2.9. The result of the difference between the mean post-test and the mean pre-test is 0.5 . Respondents only look for reference sources in the campus library. The campus library does not have many book references so that every student uses the same reference. Emotional activities, such as being interested, feeling bored, happy, excited, passionate and calm. In the excited statement if the discussion is active, the increase in activeness can be seen from the results of the mean value of the pre-test is 2.26 and the mean value of the post-test is 3.26. The result of the difference between the mean post-test and the mean pre-test is 1.00 . In the statement of learning resources that are used vary, the increase in activeness is seen from the results of the mean value of the pre-test is 2.46 and the mean value of the post-test is 2.9 . The result of the difference between the mean post-test and the mean pre-test is 0.5 . Respondents only look for reference sources in the campus library. The campus library does not have many book references so that every student uses the same reference. Emotional activities, such as being interested, feeling bored, happy, excited, passionate and calm. In the excited statement if the discussion is active, the increase in activeness can be seen from the results of the mean value of the pre-test is 2.26 and the mean value of the post-test is 3.26. The result of the difference between the mean post-test and the mean pre-test is 1.00. 46 and the mean value for the post-test was 2.9. The result of the difference between the mean post-test and the mean pre-test is 0.5 . Respondents only look for reference sources in the campus library. The campus library does not have many book references so that every student uses the same reference. Emotional activities, such as being interested, feeling bored, happy, excited, excited and calm. In the excited statement if the discussion is active, the increase in activeness can be seen from the results of the mean value of the pre-test is 2.26 and the mean value of the post-test is 3.26. The result of the difference between the mean post-test and the mean pre-test is 1.00 .46 and the mean value for the post-test was 2.9. The result of the difference between the mean post-test and the mean pre-test is 0.5 . Respondents only look for reference sources in the campus library. The campus library does not have many book references so that every student uses the same reference. Emotional activities, such as being interested, feeling bored, happy, excited, excited and calm. In the excited statement if the discussion is active, the increase in activeness can be seen from the results of the mean value of the pre-test is 2.26 and the mean value of the post-test is 3.26 . The result of the difference between the mean post-test and the mean pre-test is 1.00 . The campus library does not have many book references so that every student uses the same reference. Emotional activities, such as being interested, feeling bored, happy, excited, excited and calm. In the excited statement if the discussion is active, the increase in activeness can be seen from the results of the mean value of the pre-test is 2.26 and the mean value of the post-test is 3.26. The result of the difference between the mean post-test and the mean pre-test is 1.00 . The campus library does not have many book references so that every student uses the same reference. Emotional activities, such as being interested, feeling bored, happy, excited, excited and calm. In the excited statement if the discussion is active, the increase in activeness can be seen from the results of the mean value of the pre-test is 2.26 and the mean value of the post-test is 3.26. The result of the difference between the mean post-test and the mean pre-test is 1.00 .

Based on Table 2 shows most of the respondents in the pre-test experimental group with the highest percentage in the low learning activity category as many as 8 respondents $(53.3 \%)$, while the post-test increased to the highest percentage in the high learning activity category as many as 10 respondents $(66,7 \%)$. Based on the Wilcoxon Test which was used to analyze the results of paired 
observations of the two data, whether it was different or not, it was known that the $\mathrm{p}$ value $=0.001<$ 0.05 , which means there was a significant increase in student activity in the second semester of DIII Midwifery in Midwifery Care Courses I Pre and Post Test. In the Experimental Group. The increase before and after the intervention was 18.73 .

From the experimental group of questionnaires that were distributed, questions related to searching for literature sources, both books and the internet, found very few answers. After the researcher interviewed several students, the library had limited books. And internet sources even though the campus has provided wifi, but not all students have computer or laptop facilities. However, the results of interviews with several lecturers said that students were less active in the learning process where only a small part asked questions and tended to just wait to be given teaching materials in the form of handouts from the lecturers concerned. The main purpose of this method is to stimulate student activity and motivation in solving a problem, answering questions, adding and understanding student knowledge, and making a decision. The role of student learning in tutorials is essentially a group discussion process that requires management skills. The success of the tutorial discussion will be greatly influenced by the stages of the structure that must be followed by students which is called the Seven Jump method. In tutorial discussions affect the motivation of group members to participate.

This tutorial discussion method is expected to lead to active learning so that students learn more actively. The activeness of students in learning can stimulate and develop their talents, participants practice critical thinking and can solve problems in everyday life. The activeness of students during the teaching and learning process is the main thing that must be raised in each participant. This can be done by the teacher, namely by giving something more individual so that each individual is able to develop his enthusiasm and activity during the teaching and learning process. With tutorials or studying with small groups, participants have the opportunity to better understand the learning material. Participants can analyze aspects of the topic in depth which in lectures (lectures) can only be given in general. Tutorials give participants the opportunity to get to know other participants and can follow their way of thinking so that it helps develop their own way of thinking.

Based on table 3 in the control group, the activities of second semester students to participate in learning consist of Visual activities, oral activities, listening activities, writing activities, drawing activities, motor activities, mental activities, emotional activities, which are known to answer the questionnaire. From table 3 Visual activities such as paying attention, reading and paying attention to the work of others. Student active activities seen from Visual activities there was no increase in actively seeking and reading literature, the mean pre-test value was 2.45 and the post-test mean value was 2.45 , there was no increase. According to the researcher, this is due to several factors in the field such as the lack of complete books in the library, the lack of electronic means to support the use of the internet.

\subsection{DISCUSSION}

From the statement of the lowest difference, namely participating in active discussions based on the literature obtained. The result of the mean pre-test is 2.9 and the pre-test is 3.2 with a difference of 0.3 . In the pre-test there were 8 respondents who actively participated in the discussion and in the post-test there were 10 respondents from 22 respondents in the control group. Respondents from this Papuan cultural background tend to be indifferent and do not care about the surrounding environment. Although there is an increase, the increase is still considered low, according to the researcher, this may occur because not all respondents do not master the Askeb I course, judging from the average GPA of less than 3 (B).

In listening activities, there is a decrease in activity as seen from the mean pre-test and post-test values for each statement. The statement with the lowest increase value is to listen to the opinion of friends carefully before responding to a decrease of 0.4 . The students, who are all respondents generally from Papuan cultural backgrounds, do not understand or understand how to respect others when in discussion forums. If the opinion does not match, more often cut off the conversation. Writing activities are writing activities. Write stories, conversation results, conclusions, reports, questionnaires or copy (Sardiman, 2011). Of the two questions, the statement of the lowest increase in activeness is noting important things and things that are not understood, there is a decrease in activity

\section{Effect Of The Use Of Tutorial Methods On Liveliness Of Students In Midwifery On Askeb I In AKBID} Nyai Ahmad Dahlan Yogyakarta, Stefi Fivtri Lestari De Flores 
as seen from the results of the mean pre-test value is 2,4 and the mean value for the post-test was 2.2. The result of the difference between the mean post-test and the mean pre-test is 0.2 , there is a decrease after and before.

Activity is also characterized by drawing activities, activities marked by, for example, drawing, making graphs, maps and diagrams. Of the two statements in the questionnaire, the lowest increase in the statement can draw a concept map of the given case, the activeness seen from the results of the pre-test mean value is 2.5 and the post-test mean value is 2.3 . The result of the difference between the mean post-test and the mean pre-test is 0.2 . There is a decrease in the results after and before. Control respondents did not understand how to make a concept map, because they had never been introduced to it. Learning still uses conventional methods. The researcher will stimulate or explain the tutorial method with seven jumps and will explain how to make a concept map, so that students can learn efficiently and effectively. This is one of the things that must be done by teaching staff in displaying pictures, diagrams and concept maps. According to Gagne's theory, this is one way to increase the retention or persistence of the material.

The activity is marked by motor activities. From the two statements above, there is an increase in activity as seen from the results of the mean value of the pre-test is 2.3 and the mean value of the post-test is 2.5 . The result of the difference between the mean post-test and the mean pre-test is 0.2 with the statement trying to formulate learning objectives after completing recovery. Knowing the learning objectives also helps focus students' attention on relevant aspects. Mental activities, on the statement of critical thinking when receiving, the decrease in activity can be seen from the results of the mean value of the pre-test is 2.63 and the mean value of the post-test is 2.1 . The result of the difference between the mean post-test and the mean pre-test is 0.5. Lack of motivation to learn students in analyzing problems so that students do not think critically and only follow-up. Emotional activities, in the excited statement if the discussion is active, the increase in activity can be seen from the results of the mean pre-test value of 2.2 and the mean value of post-test of 2.2. The result of the difference between the mean post-test and the mean pre-test is 0 . The activeness of students during the teaching and learning process is the main thing that must be raised in each participant. This can be done by the teacher by giving something more individual so that each individual is able to develop his enthusiasm and activeness during the teaching and learning process. The activeness of students during the teaching and learning process is the main thing that must be raised in each participant. This can be done by the teacher by giving something more individual so that each individual is able to develop his enthusiasm and activity during the teaching and learning process. The activeness of students during the teaching and learning process is the main thing that must be raised in each participant. This can be done by the teacher by giving something more individual so that each individual is able to develop his enthusiasm and activity during the teaching and learning process.

Based on the Wilcoxon Test which was used to analyze the results of paired observations of the two data, whether it was different or not, the $\mathrm{p}$ value $=0.928>0.05$, which means that there was no significant increase in student activity in the second semester of DIII Midwifery in Midwifery Care Courses I Pre and Post. Test in the control group. The difference before and after the intervention was 0.04. Most of the respondents in the pre-test control group with the highest percentage included in the low learning activity category as many as 9 respondents $(40.9 \%)$, while in the post-test it decreased into the low learning activity category as many as 10 respondents $(45.5 \%)$. Less effective learning process affects learning activity so that it affects learning outcomes, namely student learning achievement and competence in the world of work after education. Many studies have shown that the current graduates of midwives are still unable to answer the challenges of the need for midwifery services or it can be said that the graduates produced today are still not qualified.

The conventional learning method used has several weaknesses including: easy verbalism (understanding of words), boring when used for too long, causing students to become passive. Efforts to overcome the problems that occur, including the need for the use of learning methods and media that can foster learning activity so that students are more active in interacting during the learning process. The activeness of these students will create an effective learning process and optimal learning outcomes. The view of the long-standing learning process that places learning as a process of 
transferring information or transfer of knowledge from teachers to students is getting more and more criticism.

Thordike stated that students are active in learning with his "law of exercise" which states that learning requires practice. The relationship between stimulus and response will be stronger if it is used often and will decrease or even disappear if it is never used. This means that in learning activities it is necessary to have exercises and habituation so that what is learned can be remembered longer. The more you practice, the more you will understand. This is also as stated by Mc. Keachie that the individual is an "active learning human who always wants to know". The importance of direct involvement in learning is stated by John Dewey with his "learning by doing". Learning should be experienced through direct action and must be carried out by students actively.

In this study, the validity of the questionnaire was not tested because of the limited time the researcher had. In this study, the influence of external variables was not controlled by the researcher. Psychological factors are intelligence, talent, interest. This condition affects the activity, if there is no concentration in learning, the passion for learning decreases. This psychological factor is not controlled. And Environmental Factors respondents have a cultural background. The environment affects student activity. This factor was not controlled and explained in the questionnaire.

\section{CONLUSION}

There was an effect of using the tutorial method on the activity of the second semester DIII Midwifery students in Midwifery Care I at the Nyai Ahmad Dahlan Midwifery Academy, Yogyakarta in 2013 ( $\mathrm{p}=0.001$ ). There was a significant increase in student activity in the second semester of DIII Midwifery in Midwifery Care Courses I Pre and Post Test in the Experimental Group p $=0.001<$ 0.05. The increase before and after the intervention was 18.73. There was no significant increase in student activity in the second semester of DIII Midwifery in Midwifery Care Courses I Pre and Post Test in the Control Group $p=0.928>0.05$. The difference before and after the intervention was 0.04

\section{REFERENCES}

[1] A. Timon, "Tanggung Jawab Negara Hukum Demokrasi dalam Penyelenggaraan Pelayanan Kesehatan," Soumatera Law Rev., vol. 3, no. 1, 2020.

[2] I. Junaedi, "Proses pembelajaran yang efektif," J. Inf. Syst. Applied, Manag. Account. Res., vol. 3, no. 2, 2019.

[3] I. P. Pratama and Zulhijra, "Reformasi Pendidikan di Indonesia," J. PAI Raden Fatah, vol. 1, no. 2, 2019.

[4] H. Sofiana and A. T. Hendrawijaya, "Program Keluarga Harapan dan Keberdayaan Masyarakat: Studi Pemenuhan Kebutuhan Kesehatan Masyarakat Melalui Program Keluarga Harapan," J. Pendidik. Luar Sekol., vol. 4, no. 2, 2020.

[5] S. L. Apriliani, E. E. Nikmawati, and C. Yulia, "PENGETAHUAN GIZI IBU HAMIL DI KECAMATAN KERTASARI KABUPATEN BANDUNG," Media Pendidikan, Gizi, dan Kuliner, vol. 8, no. 2, 2019, doi: 10.17509/boga.v8i2.21967.

[6] F. A. Nuurjannah, "Pembelajaran Tutorial Dengan Kemampuan Berpikir Kritis Mahasiswa Di Program Studi D3 Kebidanan Unpad," J. JKFT, vol. 5, no. 1, 2020.

[7] Y. A. Ariningtyas, "PERBANDINGAN KEPUASAN PASIEN TERHADAP PELAYANAN KEBIDANAN PADA PESERTA BPJS DAN NON BPJS," J. Med. Karya Ilm. Kesehat., vol. 4, no. 1, 2019, doi: 10.35728/jmkik.v4i1.91.

[8] H. Widaryanti, Rahayu dan Riska, "Terapi Komplementer Pelayanan Kebidanan berdasarkan bukti Scientific dan Empiris," J. Chem. Inf. Model., 2019.

[9] N. F. Nilakesuma, D. Susilawati, and K. Safitri, "Studi Kasus: Asuhan Kebidanan Pada Ibu Hamil Trimester III Dengan Menggunakan Kartu Skor Poedji Rochjati," SEAJOM Southeast Asia J. Midwifery, vol. 5, no. 2, 2019, doi: 10.36749/seajom.v5i2.72.

[10] W. Sulistyawati and N. Ayati Khasanah, "Asuhan Kebidanan Pada Ibu Hamil Dengan Anemia Dan Faktor Yang Melatarbelakangi," Pros. Semin. Nas. Has. Penelit. Dan Pengabdi. Masy. Seri Ke-3 Tahun 2019, 2019.

[11] I. Pratiwi, "EFEK PROGRAM PISA TERHADAP KURIKULUM DI INDONESIA," $J$. 
Pendidik. dan Kebud., vol. 4, no. 1, 2019, doi: 10.24832/jpnk.v4i1.1157.

[12] V. Indriyani, M. Zaim, A. Atmazaki, and S. Ramadhan, "LITERASI BACA TULIS DAN INOVASI KURIKULUM BAHASA," KEMBARA J. Keilmuan Bahasa, Sastra, dan Pengajarannya, vol. 5, no. 1, 2019, doi: 10.22219/kembara.vol5.nol.108-118.

[13] N. U. Muhammad, S. Herlina, and M. Firmansyah, "Analisa Proses Pembelajaran Berbasis Student Centered Learning, Problem Based Learning, Integrated , Community Based Learning, Electives, Systematic (SPICES) Terhadap Indeks Prestasi Mahasiswa Fakultas Kedokteran," J. Univ. Islam Malang, vol. 8, 2020. 